\title{
Somatostatin and adrenocorticotrophic hormone like immunoreactivity in small cell carcinoma of the lung
}

\author{
MF CHRETIEN, $*$ A POUPLARD-BARTHELAIX, $\dagger$ MP DUBOIS $\ddagger$ C SIMARD $\ddagger$ \\ A RÈBEL*
}

From the ${ }^{*}$ Laboratoire d'Histologie-Embryologie-Cytologie, $\uparrow$ Unite de Neuroimmunologie, and $\ddagger$ Laboratoire
d'Anatomie Pathologie, Centre Hospitalier Universitaire, Angers, France

SUMMARY The immunocytological detection of adrenocorticotrophic hormone (ACTH) and somatotropin release inhibitor factor (SRIF) like immunoreactivity was carried out on tumour cells from bronchial brush smears in 39 cases of lung tumours. Results obtained were compared with the cytological and histological diagnosis and confirmed the high incidence of ACTH synthesis by malignant bronchial carcinoma cells: the same phenomenon also seems to occur for somatostatin. The concomitant detection of ACTH and SRIF like immunoreactivity seems to be highly suggestive of small cell carcinoma and indicates that the immunocytological detection of hormones carried out at the same time as cytological examination can improve the accuracy of the diagnosis.

Endocrine cells analogous to those found in the gastrointestinal tract and pancreas have been recognised in normal human bronchial mucosa by ultrastructural and histochemical techniques. Some types of anaplastic carcinoma may originate from such cells. $^{1-3}$ Bronchial carcinomas, mostly of oat cell type, are known to synthesise many different peptide hormones. Clinical syndromes are not always present, being reported in only $10 \%$ of all patients with lung cancer, ${ }^{4}$ but in recent years the development of sensitive techniques has led to the detection of several peptides in $50 \%$ of cases. Ectopic production of somatostatin (somatotropin release inhibitory factor, or SRIF) has been reported to occur mainly in association with small cell carcinoma. ${ }^{56}$

We report here the immunocytological detection of both SRIF and ACTH hormones in cells obtained from bronchial brush smears and suggest that this detection used in conjunction with cytological examination may be useful in diagnosis.

\section{Material and methods}

\section{PATIENTS}

Thirty nine patients showing opacity on radiography and abnormal appearance on bronchoscopy were investigated. In all patients bronchial brush smears were obtained at the time of the fibroscopic examination.

Accepted for publication 14 November 1985
CYTOLOGICALEXAMINATION

For each patient the bronchial brush smear sample was mixed with $5 \mathrm{ml}$ of saline solution $(0.9 \%)$ and centrifuged for 10 minutes in a Cytospin (Shandon). In this way cells were collected directly on the microscope slides. Depending on the size of the samples, we tried to obtain at least 12 slides, of which six were kept for the cytological study and six for the immunocytological assay. The cytological study was carried out using Papanicolaou's stain after fixation in a alcohol-ether mixture $(50 \% \mathrm{vol} / \mathrm{vol})$.

\section{IMMUNOCYTOLOGICAL ASSAY}

The presence of intracellular hormones was detected by the classical indirect immunofluorescence test after mild acetone fixation ( 3 minutes) with polyclonal but specific antihormone antisera (gift from MPD). Dilutions of antisera and the absence of cross reactivity between all antisera used were verified on frozen pancreas sections for the anti-SRIF (at $1 / 100$ dilution) and human and guinea pig pituitary sections for the different anti-ACTH antisera (at 1/100 dilution). After incubation for one to two hours with the hormone antiserum and washing in phosphate buffer the cells were counterstained with a goat antirabbit IgG conjugated with fluorescein isothiocyanate $(G / R$ FITC, Nordic Laboratories). The slides were then mounted in glycerol and visualised with a Zeiss orthoplan photomicroscope. As a result of the insufficient 
number of slides obtained from some patients, only 28 patients were tested with the anti-1-24 ACTH and 31 with the anti-17-39 ACTH. For each patient one slide was kept as a control and the cells exposed to normal rabbit serum followed by the fluorescein isothiocyanate conjugated goat antirabbit IgG. The specificity of the staining reaction was tested by using the same antisera preabsorbed with the corresponding hormone.

For the absorption experiment $100 \mu \mathrm{l}$ of the ACTH antiserum at $1 / 50$ dilution were absorbed with $200 \mu \mathrm{l}$ of ACTH 1-24 (Sigma) as follows: $0.5 \mathrm{mg}$ of ACTH 1-24 diluted in $100 \mu \mathrm{l}$ of sterile distilled water; $20 \mu \mathrm{l}$ of the dilution was used for the absorption. The same method was used for the somatostatin.

Cells showing positive staining were identified by a double technique: after the immunofluorescence test the positive cells were photographed, the same slide was stained again by Papanicolaou's method, and each field photographed again. We were unable to test for the presence of both hormones in the same cells as both antihormone antisera (rabbit) used were obtained from the same animal.
Results

\section{CYTOLOGICAL RESULTS}

Malignant cells were diagnosed using the World Health Organisation classification criteria. $^{7}$ The study was focused mainly on the commonest types of lung tumours - the epidermoid and small cell typesbecause of the differential diagnostic problems encountered. Of the 39 specimens tested, 24 were identified as small cell carcinoma on cytological examination. This diagnosis was confirmed by histological study in 18 cases. Eight cases were identified as epidermoid carcinoma on cytological and histological examination. In four no malignant cells were detected on either the brush smear sample or biopsy specimen. They were taken as controls.

\section{IMMUNOCYTOLOGICAL RESULTS}

Positive staining with either the anti-SRIF or the antiACTH with both antisera was obtained in 26 cases (Table 1).

\section{SRIF LIKE IMMUNOREACTIVITY}

Positive cytoplasmic staining was detected with the

Table 1 Histological and cytological diagnoses together with results of indirect immunofluorescence staining on bronchial brush smears for SRIF and ACTH like immunoreactivity in 35 men with lung tumours*

\begin{tabular}{|c|c|c|c|c|c|}
\hline Case no & Cytological diagnosis & SRIF & $A C T H 1-24$ & ACTH 17-39 & $\begin{array}{l}\text { Histological } \\
\text { diagnosis }\end{array}$ \\
\hline $\begin{array}{l}1 \\
2 \\
3 \\
4 \\
5 \\
6 \\
7 \\
8 \\
9 \\
10 \\
11 \\
12 \\
13 \\
14 \\
15 \\
16 \\
17 \\
18 \\
19 \\
20 \\
21 \\
22 \\
23 \\
24 \\
25 \\
26 \\
27 \\
28 \\
29 \\
30 \\
31 \\
32 \\
33 \\
34 \\
35 \\
\text { Total }\end{array}$ & $\begin{array}{l}\text { SCC } \\
\text { SCC } \\
\text { SCC } \\
\text { SCC } \\
\text { EC } \\
\text { Suspect undetermined cells } \\
\text { SCC } \\
\text { SCC } \\
\text { SCC } \\
\text { EC } \\
\text { SCC } \\
\text { SCC } \\
\text { SCC } \\
\text { No diagnosis } \\
\text { SCC } \\
\text { EC } \\
\text { SCC } \\
\text { SCC } \\
\text { SCC } \\
\text { SCC } \\
\text { SCC } \\
\text { EC } \\
\text { SCC } \\
\text { EC } \\
\text { EC or adenocarcinoma } \\
\text { EC } \\
\text { SCC } \\
\text { EC } \\
\text { SCC } \\
\text { EC } \\
\text { SCC } \\
\text { SCC } \\
\text { SCC } \\
\text { SCC } \\
\text { SCC }\end{array}$ & $\begin{array}{l}+ \\
+ \\
++ \\
+ \\
++ \\
+ \\
+ \\
+ \\
+ \\
+ \\
+ \\
+ \\
++ \\
+ \\
+ \\
+ \\
+ \\
+ \\
+ \\
- \\
+ \\
+ \\
+ \\
+ \\
+ \\
+ \\
+ \\
+ \\
+\end{array}$ & $\begin{array}{l}+ \\
+ \\
+++ \\
++ \\
+ \\
+ \\
+ \\
++ \\
+ \\
+ \\
+ \\
+ \\
+ \\
+ \\
+ \\
+ \\
+ \\
++ \\
++ \\
++ \\
+ \\
+\end{array}$ & $\begin{array}{l}++ \\
- \\
++ \\
- \\
- \\
+++ \\
+ \\
- \\
++ \\
\pm \\
- \\
- \\
- \\
- \\
\overline{+} \\
++ \\
- \\
- \\
++ \\
+ \\
+ \\
+ \\
+ \\
+ \\
+\end{array}$ & $\begin{array}{l}\text { EC or SCC } \\
\text { SCC } \\
\text { SCC } \\
\text { No diagnosis } \\
\text { EC } \\
\text { EC } \\
\text { SCC } \\
\text { SCC } \\
\text { SCC } \\
\text { EC } \\
\text { No diagnosis } \\
\text { SCC } \\
\text { SCC } \\
\text { SCC } \\
\text { No diagnosis } \\
\text { EC } \\
\text { SCC } \\
\text { SCC } \\
\text { SCC } \\
\text { SCC } \\
\text { SCC } \\
\text { EC } \\
\text { No diagnosis } \\
\text { EC } \\
\text { Adenocarcinoma } \\
\text { EC } \\
\text { SCC } \\
\text { EC } \\
\text { SCC or EC } \\
\text { EC } \\
\text { SCC } \\
\text { SCC } \\
\text { SCC } \\
\text { SCC } \\
\text { SCC }\end{array}$ \\
\hline
\end{tabular}

SCC $=$ Small cell carcinoma; $\mathrm{EC}=$ Epidermoid carcinoma.

*In 26 men positive cells were found with either anti-SRIF or anti-ACTH antisera. 
anti-SRIF antiserum in 19 cases; 18 of these were diagnosed as small cell carcinoma on cytological examination. Study of the biopsy specimen confirmed the diagnosis in 13 cases, did not allow a diagnosis in three, and was uncertain in two (Table 2).

\section{ACTH LIKE IMMUNOREACTIVITY}

In 22 cases, cells positive for either 1-24 or 17-39 ACTH immunoreactivity were detected. Thirteen of these cases were considered to be small cell carcinoma on both cytological and histological examination. Twenty four cases were tested with the two different 1-24 and 17-39 ACTH antisera. In eight cases both immunoreactivities were detected; all were found to be small cell carcinoma on cytological examination, but in five cases only was the diagnosis confirmed on histological examination (Table 3).

\section{SRIF AND ACTH LIKE IMMUNOREACTIVITY}

The existence of cells positive for both SRIF and
ACTH immunoreactivity was shown only in cases of small cell carcinoma confirmed on both cytological and histological examination (11 of 18 cases). The number of cells stained by both antisera varied, and the intensity of staining was slightly different.

IMMUNOFLUORESCENCE (Fig. 1)

The immunofluorescent staining obtained was quite uniform in all the cases found to be small cell carcinoma; a thin ring of bright cytoplasmic staining in cells often forming clusters, the nucleus always remaining unstained. In the three cases of the epidermoid type, the cells appeared larger with more abundant cytoplasm that was positive with one or two of the tested antisera. The specificity of the staining was confirmed by the absorption experiment, as positivity was inhibited in all cases by preabsorption of the antiserum with the corresponding hormone.

No tumour cells were stained after exposure to normal rabbit serum, and only in some cases was a

Table 2 The use of indirect immunofluorescence on cells obtained from bronchial brush smears, showing positive staining for SRIF and ACTH like immunoreactivity in 13 of 18 patients with SCC diagnosed by cytological and histological examination

\begin{tabular}{|c|c|c|c|c|c|}
\hline \multicolumn{2}{|c|}{ Type of tumour } & \multirow[b]{2}{*}{ No of cases $(n=35)$} & \multirow[b]{2}{*}{ SRIF } & \multirow[b]{2}{*}{$A C T H$} & \multirow{2}{*}{$\begin{array}{l}\text { SRIF } \\
\text { and } \\
A C T H\end{array}$} \\
\hline $\begin{array}{l}\text { On cytological } \\
\text { examination }\end{array}$ & $\begin{array}{l}\text { On histological } \\
\text { examination }\end{array}$ & & & & \\
\hline $\begin{array}{l}\text { SCC } \\
\text { SCC } \\
\text { SCC } \\
\text { No diagnosis } \\
\text { EC } \\
\text { Suspect undetermined } \\
\text { cells } \\
\text { EC or adenocarcinoma }\end{array}$ & $\begin{array}{l}\text { SCC } \\
\text { No diagnosis } \\
\text { SCC or EC } \\
\text { SCC } \\
\text { EC } \\
\text { EC } \\
\text { Adenocarcinoma }\end{array}$ & $\begin{array}{r}18 \\
4 \\
2 \\
1 \\
8 \\
1 \\
1\end{array}$ & $\begin{array}{r}13 \\
3 \\
2 \\
1\end{array}$ & $\begin{array}{r}13 \\
4 \\
2 \\
2\end{array}$ & $\begin{array}{r}10 \\
3 \\
2 \\
0\end{array}$ \\
\hline
\end{tabular}

SCC $=$ Small cell carcinoma; EC = Epidermoid carcinoma.

Table 3 Results of indirect immunofluorescence staining on cells from bronchial brush smears in eight patients with lung tumours with discrepancies in cytological and histological examination

\begin{tabular}{|c|c|c|c|c|c|c|}
\hline Case no & Cytological diagnosis & Histological diagnosis & SRIF & ACTH $1-24$ & ACTH 17-39 & Comments \\
\hline 1 & SCC & SCC or EC & + & + & ++ & Considered to be SCC, \\
\hline 4 & SCC & No diagnosis & +++ & ++ & - & $\begin{array}{l}\text { Considered to be SCC, } \\
\text { chemotherapy given }\end{array}$ \\
\hline 6 & $\begin{array}{l}\text { Suspect undetermined } \\
\text { cells }\end{array}$ & EC & - & - & - & $\begin{array}{l}\text { Considered to be EC, } \\
\text { pneumonectomy, } \\
\text { performed }\end{array}$ \\
\hline 11 & SCC & No diagnosis & - & + & ++ & $\begin{array}{l}\text { Considered to be SCC, } \\
\text { chemotherapy given }\end{array}$ \\
\hline 14 & No diagnosis & SCC & - & - & - & $\begin{array}{l}\text { Considered to be SCC, } \\
\text { chemotherapy given }\end{array}$ \\
\hline 15 & SCC & No diagnosis & ++ & + & - & $\begin{array}{l}\text { Considered to be iliac } \\
\text { metastasis, SCC, } \\
\text { chemotherapy given }\end{array}$ \\
\hline 23 & SCC & No diagnosis & +++ & + & ++ & $\begin{array}{l}\text { Considered to be } \\
\text { cerebral metastasis. } \\
\text { Patient refused } \\
\text { chemotherapy }\end{array}$ \\
\hline 29 & SCC & $\mathrm{EC}$ or SCC & + & - & + & $\begin{array}{l}\text { Considered to be SCC, } \\
\text { chemotherapy given }\end{array}$ \\
\hline
\end{tabular}




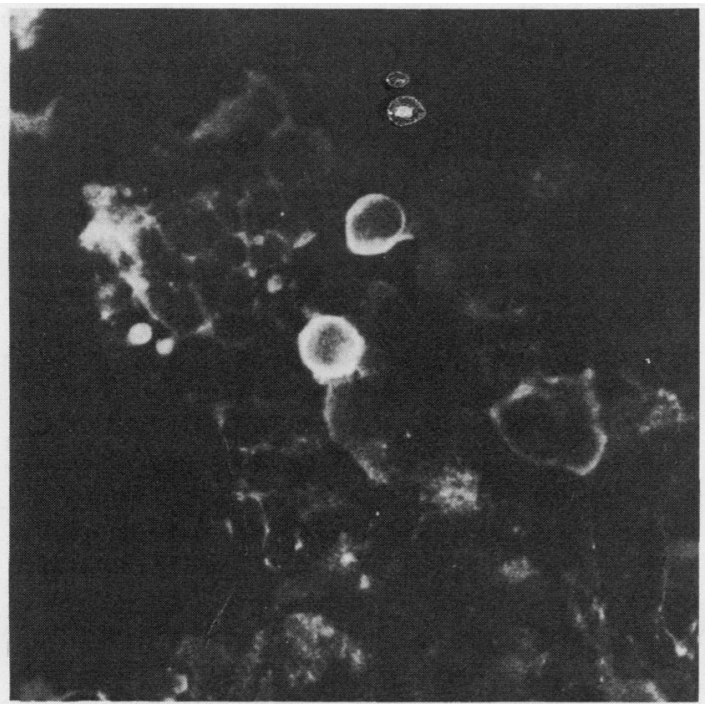

Fig. 1 Immunofluorescence staining on bronchial brush smears in one case of small cell carcinoma with specific antiSRIF antiserum.

faint non-specific fluorescence of bronchial cells or macrophage detected. Similarly, no staining could be detected in the benign cases tested.

\section{Discussion}

Numerous peptides, including some neuropeptides, are known to be secreted by tumour cells; among pituitary hormones ACTH has been the most commonly reported. ${ }^{489}$

Bronchial carcinoma is one of the most common types of tumour associated with the production of ectopic hormone. ${ }^{8}$ With the development of sensitive assays it has been recognised that all lung tumours may be associated with the production of peptides with hormonal activity, although this phenomenon seems to be more common in the small cell variety. Somatostatin in association with other neuropeptides ${ }^{1011}$ was recently detected in tumour extracts $^{5}$, tumour cell cultures, ${ }^{12}$ and plasma in patients with oat cell carcinoma, but the immunocytological detection on tumour cells has not been reported.

Results obtained in our study support the known high prevalence of tumour cells producing ACTH and show that the same phenomenon can occur for somatostatin.

Many problems are still encountered in the histological classification of lung tumours, particularly anaplastic carcinoma as defined by the WHO classification. ${ }^{713}$ Detection of hormone, in some cases at least, may help to establish the diagnosis at a fairly early stage of development and to identify the specific kind of tumour. ${ }^{4}$ Our results confirm previous work and show the high prevalence of somatostatin in oat cell carcinoma. Clinical signs of excessive secretion of SRIF have not been described in association with lung carcinoma, but the immunoreactivity found in tumour extracts is sometimes accompanied by a detectable activity in plasma. ${ }^{14}$ This has already been proved for several hormones and may reflect a low rate of synthesis and release, a rapid plasma clearance, or perhaps intermittent release. ${ }^{15}$ Nevertheless, with the availability of sensitive radioimmunoassay raised SRIF plasma values may serve as a tumour marker. Pro-ACTH (a glycopeptide precursor) has also been proposed as an important tumour marker: whether it is or not needs to be investigated. ${ }^{9}$

The value of the cytological diagnosis on bronchial smears enriched by cytospinning has been proved. We have used this technique for over 10 years with good histological agreement. Immunochemical detection of hormones combined with cytological examination may further improve the value and rapidity of diagnosis and thus be useful in treatment. Although more patients and other types of tumour need to be tested, preliminary results obtained tend to show that the concomitant detection of the two hormones, ACTH and somatostatin, is highly suggestive of small cell carcinoma. Moreover, such findings may lead to a functional classification of lung tumours by studying the cytological characteristics of cells secreting specific peptides.

Many questions remain on the primitive or stem cell implicated in each type of lung tumour. The finding of transitional forms between small cell carcinoma, differentiated squamous cell carcinoma, and adenocarcinoma has led to a unified theory of lung cancer in man. The commonly associated production of ectopic hormone raises the question of different stages of cell differentiation. Results obtained in this study show that the detection of hormones with a panel of specific antisera or monoclonal antisera, or both, may well be useful in detecting tumour markers. Radioimmunoassay on the final histological specimen is needed to confirm the reliability of the cytological method.

Recent results obtained for the expression of neural filament type proteins in malignant cells of bronchial carcinoma ${ }^{15}$ indicate that combining the two techniques will be even more useful.

\section{References}

${ }^{1}$ Bensch KG, Corrin B, Pariente R, Spenser H. Oat cell carcinoma of the lung. Its origin and relationship to bronchial carcinoid. Cancer 1968;22:1163-72. 
${ }^{2}$ Gould VE, Chejfec G. Ultrastructural and biochemical analysis of "undifferentiated" pulmonary carcinomas. Hum Pathol 1978;9:377-84.

${ }^{3}$ Hage E, Hage S, Juel G. Endocrine-like cells of the pulmonary epithelium of human adult lung. Cell Tissue Res 1978;178:39-48.

${ }^{4}$ Yesner R. Spectrum of lung cancer and ectopic hormones. Pathol Ann 1978;13:207-40.

${ }^{5}$ Penman E, Wass JAH, Besser GH, Rees LH. Somatostatin secretion by lung and thymic tumors. Clin Endocrinol 1980; 13:613-20.

${ }^{6}$ Waliack SR, Royston I, Toettle R, Wehl H, Deftos LJ. Plasma calcitonin as a marker of disease activity in patients with small cell carcinoma of the lung. $J$ Clin Endocrinol Metab 1981;53:602-6.

${ }^{7}$ Kreybeg L. Classification histologique des cancers du poumon. 2nd ed. Geneva: OMS, 1981.

${ }^{8}$ Rees LH. Ectopic production of hormones by tumours. In: Besser M, ed. Advanced medicine. 13. London: Pitmann Medical, 1977.

${ }^{9}$ Wolfsen AR, Odell WD. Pro-ACTH: use for early detection of lung cancer. Am J Med 1979;66:765-7.

${ }^{10}$ Mosonil L, Szilagyl G, Szatloczky E, Graf L, Palasthy E. Oat-cell bronchial carcinoma and cathecholamine production. $\mathrm{Br}$ Med J 1971:173:373-4.

${ }^{11}$ Wood SM, Wood JR, Ghatei MA, Lee YC, O'Shanghnessy D, Bloom SR. Bombesin, somatostatin and neurotensin-like immu- noreactivity in bronchial secretion. $J$ Clin Endocrinol Metab 1981;53:1310-2.

${ }^{12}$ Sza BO M, Berelowitz M, Pettengile OS, Sorenson GP, Frohman LA. Ectopic production of somatostatin-like immunobioactivity by cultured human pulmonary small cell carcinoma. J Clin Endocrinol Metab 1980;51:879-87.

${ }^{13}$ McDowell EM, Becci PJ, Barrett LA, Trump BF. Morphogenesis and classification of lung cancer. In: Curtis C, ed. Pathogenesis and therapy of lung cancer, New York: Marcel Dekker, 1978:445-519.

${ }^{14}$ Roos AB, Lindall AW, Ells J, et al. Increased plasma and tumor somatostatin-like immunoreactivity in medullary thyroid carcinoma and small cell lung cancer. $J$ Clin Endocrinol Metab 1981;52:187-94.

${ }^{15}$ Lehto VP, Stenman S, Miettinen M, Dahl D, Virtanen I. Expression of a neural type of intermediate filament as a distinguishing feature between oat cell carcinoma and other lung cancers. Am J Pathol 1983;110:113-8.

Requests for reprints to: Dr MF Chretien, Laboratoire d'Histologie-Embryologie-Cytologie, Faculté de Médecine, 49045-Angers, Cédex, France. 